\title{
Legal Arrangements on Management of Coastal Areas in the Region
}

\author{
Khelda Ayunita, ${ }^{*}$ Achmad Ruslan, ${ }^{* *}$ Abd. Razak, ${ }^{* *}$ Hamzah Halim ${ }^{* *}$ \\ *Doctoral Student, Faculty of Law, Hasanuddin University, Indonesia \\ ${ }^{* *}$ Professor, Faculty of Law, Hasanuddin University, Indonesia
}

\begin{abstract}
This study aims to find the legal politics of coastal marine areas management, arrangements for management of coastal marine areas according to the 1945 Constitution of the Republic of Indonesia, and regulations for management of coastal marine areas. This type of research is normative legal research, using a conceptual approach and a statute approach. The legal materials used in this study consist of primary, secondary and tertiary legal materials. The legal material that has been described in accordance with the main problem is then distributed, explored and then given an argument so that the whole forms a logically interconnected whole about the disclosure of logical rationale and the ontological basis for the issuance of laws governing coastal marine areas. The results of this study indicate that the regulation of management of marine resources in Indonesia still occurs disproportionate tugging of authority between the Central Government and Local Governments resulting in tensions that lead to a conflict of authority so that there is a need for assertiveness and clarity in the division of authority for management of marine resources between the Central Government and The Regional Government proportionally really takes into account national interests and the interests of the region itself.
\end{abstract}

Keywords: coastal marine areas, legal arrangements, management.

DOI: $10.7176 / \mathrm{JLPG} / 95-15$

Publication date:March $31^{\text {st }} 2020$

\section{Introduction}

Unitary State of the Republic of Indonesia is an archipelagic country characterized by the archipelago with territories whose boundaries and rights are stipulated by law. ${ }^{1}$ Indonesia is also a scattered archipelago in the world consisting of around $17,508^{2}$ islands with a sea area of around 5.8 million $\mathrm{km}^{2}$ and a line stretch of 81,000 $\mathrm{km}^{2}$. Most of the islands are small islands that have a wealth of natural resources and environmental services that are very potential for economic development. ${ }^{2}$ The characteristics of the archipelago here illustrate the existence of a series of islands, including all contents contained in water, on land, and the air above. ${ }^{3}$ The whole mechanism of the relationship between God's creatures in the living space of the unitary state of the Republic of Indonesia is what is referred to as the ecosystem that we have inherited from generation to generation. ${ }^{4}$

Sea is one of the sources of wealth of a country, because it saves natural resources very much, be it fish, seaweed, rocks, coral, and others. One of the lucky countries by the grace of the god associated with the marine area is Indonesia. ${ }^{5}$ The main role of the state in a country is to realize the ideals of the nation itself listed in each constitution or the Constitution of the country concerned. ${ }^{6}$ The ideals of the Indonesian people as stated in the

\footnotetext{
${ }^{1}$ Article $25 \mathrm{~A}$ of the 1945 Constitution of the Republic of Indonesia

2 Farida Patittingi, 2013, Dimensi Hukum Pulau-Pulau Kecil di Indonesia (The Legal Dimension of Small Islands in Indonesia), Rangkang Education Yogyakarta, p. 1

${ }^{3}$ Department of Maritime Affairs and Fisheries of the Republic of Indonesia, 2001, Pedoman Umum Pengelolaan Pulau-pulau Kecil yang berkelanjutan dan berbasis masyarakat (General Guidelines for the Management of Small Islands that are sustainable and community-based), Jakarta, p. 5, See also Sugeng Budiharsono, 2001, Teknik Analisis Pembangunan Wilayah Pesisir dan Lautan (Coastal and Ocean Territory Development Analysis Techniques), Jakarta, p. 1, concerning the National Commission on the Study of Marine Fisheries Resources (1998) reported that the sustainable potential of Indonesia's marine fisheries resources is 6,167,940 tons per year with the largest portion of pelangis fish species at 975,050 tons or at 15.81 percent. Other high-value fishery commodities, such as crabs, mangroves or small crab, can be found geographically in all Indonesian waters. In addition to fish, seaweed species that can be used both for cosmetics and medicine are found in almost all Indonesian waters. In addition to fish, types of seaweed that can be used both for cosmetics and medicine are found in almost all Indonesian waters.

${ }^{4}$ Jimly Asshiddiqie, 2010, Green Constitution, Nuansa Hijau Undang-Undang Dasar Republik Indonesia Tahun 1945 (Green Constitution, Green Shades of the 1945 Constitution of the Republic of Indonesia), Rajawali Pers, Jakarta, p. 91

${ }^{5}$ Abd. Asis, et.al., Strategic policy of the Government of Indonesia In the Field of Maritime and Fisheries Affairs, International Journal of Scientific and Research Publications, Volume 6, Issue 12, December 2016, p. 238

${ }^{6}$ An An Chandrawulan, 2014, Hukum Perusahaan Multinasional, Liberalisasi Hukum Perdagangan Internasional dan Hukum (Multinational Corporate Law, Liberalization of International Trade Law and Law), PT. Alumni, Bandung, p. 15
} 
1945 Constitution of the Republic of Indonesia ${ }^{1}$ as the basis of the Constitution of the Republic of Indonesia, both before and after the amendment, has a strong spirit in realizing the welfare of Indonesian citizens. Understanding the national interest in realizing the welfare of Indonesian citizens can move from the objective of establishing the Republic of Indonesia as stipulated in the Pancasila ideology and the Opening of the 1945 Constitution of the Republic of Indonesia. The basic formula "Social justice for all Indonesian people" is then manifested into the body of the constitution to be used as a guideline for national life in the administration of the state.

One of the objectives of realizing "social justice for all Indonesian people" is outlined in Article 33 of the 1945 Constitution of the Republic of Indonesia, which is the principle and mandate of the constitution that underlies the formation of all laws and regulations in the field of economy and welfare of Indonesian citizens. The constitution mandates that national economic development must be based on democratic principles that can create the realization of Indonesia's economic sovereignty. The basic concept contained in Article 33 paragraph (3) of the 1945 Constitution of the Republic of Indonesia that "the earth, water and natural resources contained therein are controlled by the state for the greatest prosperity of the people" is a constitutional foundation and at the same time the direction of regulating several matters relating to state control over natural resources for the allocation of the welfare of the people of Indonesia. State control over Natural Resources, specifically included in the management of marine resources. Marine resources are strategic economic resources to improve the welfare of the people of Indonesia. Marine resources must be utilized as much as possible for the prosperity of the people.

The constitutional mandate for the implementation of the broadest possible autonomy within the framework of the Unitary State of the Republic of Indonesia in Law No. 23 Year 2014 concerning Regional Government is further elaborated in Article 2 which states the Unitary State of the Republic of Indonesia is divided into Provincial Regions, and the Province Region is divided into Regency and City Regions. Furthermore Article 3 confirms that the Provincial Region and Regency/City Region are Regions and each of them has Regional Government. Concurrent governmental affairs are then divided into regional authorities consisting of compulsory governmental affairs and optional governmental affairs. One of the governmental affairs options includes maritime affairs and fisheries (Article 11 paragraph (1)). Article 14 paragraph (1) of Law No. 23 Year 2014 states that the Implementation of Government Affairs in the fields of forestry, maritime affairs and energy and mineral resources is shared between the central Government and the Provincial Regions. In Article 14 paragraph (5) it is stated that the producing regency/city Region and not the producer obtains the profit sharing from the administration of Government Affairs as referred to in paragraph (1), and in paragraph (5) hereinafter stipulates the determination of the producing regency/city region for the calculation of marine profit sharing is a marine product within the boundary of an area of 4 (four) miles measured from the coastline towards the open sea and/or towards archipelagic waters. Law No. 23 Year 2014 only regulates management areas which are under the jurisdiction of the Province as mentioned in Article 27 paragraph (3) where regional sea management authority is regulated at most 12 sea oceans measured from the coastline towards the open sea and/or towards archipelago waters.

In the history of local governance in Indonesia, decentralization and centralization have shifted several times. There are many factors that influence the ups and downs of decentralization, especially the nature of state power (central government) whether moving in a democratic or authoritarian direction. However, the shift that occurred must of course remain in the corridor of the 1945 Constitution of the Republic of Indonesia as the highest law. According to the concept of a unitary state decentralization comes from centralization. However, on the other hand decentralization and regional autonomy are provisions of the 1945 Constitution of the Republic of Indonesia. ${ }^{2}$

This means that the unitary state must be run in tandem with regional autonomy. Centralization must not eliminate the existence of regional autonomy as constitutional mandate. In Law Number 23 Year 2014 concerning Regional Government, there is a tendency towards centralization. These trends can be identified both in terms of the concept of the distribution of functions, the authority to form regional regulations, as well as in the distribution of authority, especially for the management of natural resources, forestry, and mining. ${ }^{3}$ The preamble of Law No.

\footnotetext{
${ }^{1}$ In the formulation of the 1945 Constitution of the Republic of Indonesia there is an explicit or implicit views and fundamental values, the 1945 Constitution of the Republic of Indonesia besides being a political constitution is also an economic constitution, even a social constitution. The 1945 Constitution of the Republic of Indonesia as a state constitution in substance is not only related to the unification of state institutions and government structures. But more than that, the constitution also has dimensions of economic regulation and social welfare as stipulated in Article 33 of the 1945 Constitution of the Republic of Indonesia.

2 Article 18 of the 1945 Constitution stipulates that "The division of Indonesian territory on a large and small basis with the form of government structure shall be determined by law, by observing and bearing in mind the deliberative basis in the state government system, and the right of origin in special regions".

${ }_{3}$ Muhammad Ali Safa'at, Sentralisasi dalam UU Nomor 23 Tahun 2014 tentang Pemerintahan Daerah (Centralization in Law Number 23 Year 2014 concerning Regional Government), delivered at the focus group discussion "Inventory Issues Law No.23
} 
23 Year 2014 states that the efficiency and effectiveness of the administration of regional government need to be improved by paying more attention to aspects of the relationship between the central and regional governments and regions, the potential and diversity of the region, as well as the opportunities and challenges of global competition in the unity of the state governance system.

The issuance of Law No.23 of 2014 states that the efficiency and effectiveness of the administration of regional government need to be improved by paying more attention to aspects of the relationship between the central and regional governments and regions, the potential and diversity of the region, as well as the opportunities and challenges of global competition in the unity of the state governance system. Based on the explanation, the problem that will be examined in this paper is how is the Political Law of Coastal Sea Area Management? and how is the legal politics of coastal marine areas management?, how is arrangements for management of coastal marine areas according to the 1945 Constitution of the Republic of Indonesia?, and how is regulations for management of coastal marine areas?

\section{Research Method}

This type of research is a normative legal research, using a conceptual approach and a statute approach. ${ }^{1}$ The legal materials used in this study consist of primary, secondary and tertiary legal materials. ${ }^{2}$ The legal material that has been described in accordance with the main problem is then distributed, explored and then given an argument so that the whole forms a logically interconnected whole concerning the disclosure of logical rationale and ontological basis for the issuance of laws governing the management of the coastal marine area and the laws of the local government governing management of coastal marine areas.

\section{Results and Discussion}

\section{A. Legal Political of Coastal Sea Management}

Legislation as a legal product becomes a very important tool in the implementation of state life. ${ }^{3}$ The legal basis of the regulatory function, Article 33 paragraph (1) and Paragraph (2) of the 1945 Constitution of the Republic of Indonesia, in its substance contains the words controlled by the State. This shows that the State has the right and obligation to regulate the State so that it can be well ordered. Regulations through regulations that serve as guidelines for acting in a country. The government makes the rules regulated in Article 5 paragraph (1) and Paragraph (2) of the 1945 Constitution of the Republic of Indonesia. Paragraph (1), the President has the right to submit a bill to the House of Representatives; Paragraph (2) The President establishes Government Regulations to implement the Act accordingly. The state through the executive government together with the legislature in accordance with the authority stipulated in Article 5 to make regulations on the coastal sea area is to arrange the institutional structure, the relationship between the government and economic actors and the people as a whole so that they can function properly. The purpose of the regulation is to create security, calm, order, happiness, usefulness, justice, towards social welfare for all people. The term "Legal Political" has been interpreted as the politics of legal development and the politics of renewal. There is also a phrase that says: "the essence of legal development is legal renewal". In addition, there are also interpretations of legal development, namely: the formation of new laws (including renewing old laws), and the law for development. In relation to renewal, legal politics is the politics of law for community renewal (an expression from Roscoe Pound which says: law as a tool of social engineering) ${ }^{4}$

Padmo Wahjono defines legal politics as the basic policy that determines the direction, form and content of the law to be formed. ${ }^{5}$ Teuku M. Radhie defines the legal politics as a statement of the will of the state authorities regarding the law in force in their territory, and regarding the direction of the development of the law to be built. ${ }^{6}$

of 2014 concerning Regional Government" organized by the Association of Regency Governments throughout Indonesia (Asosiasi Pemerintah Kabupaten seluruh Indonesia/APKASI). Jakarta, 15 September 2015.

${ }^{1}$ Peter Mahmud Marzuki, 2003, Penelitian Hukum (Legal Reaearch), Prenada Media, Jakarta.

${ }^{2}$ Roni Hanitijo Soemitro, Metodologi Penelitian Hukum dan Jurimetri (Legal and Jurimetry Research Methodology), Penerbit Ghalia Indonesia Jakarta, 1998, p. 125

3 Achmad Ruslan, 2011, Peraturan Perundang- $U^{\text {ndangan Sebagai Sarana Hukum Penyelenggaraan Negara (Legislation as a Means of State Administration), Professor's Oration }}, \mathrm{p}^{6}$

4 Bagir Manan, Politik Hukum Untuk Otonomi Daerah (Legal Politic for Regional Autonomy), Public Lecture at the Postgraduate Faculty of Law at Syiah Kuala University, Banda Aceh, 2013, p. 1-2

${ }^{5}$ Padmo Wahjono, Indonesia Negara Berdasarkan atas Hukum (Indonesia is Based on Law), Ghalia Indonesia, Jakarta, 1986, p. 160

${ }^{6}$ Teuku M. Radhie, Pembaharuan dan Politik Hukum dalam Rangka Pembangunan Nasional (Legal Reform and Politics in the Framework of National Development), Jurnal Prisma, No. 6 Tahun II, 1973, p. 4 
Satjipto Rahardjo defines legal politics as the activity of choosing the means to be used to achieve certain social and legal goals in society. ${ }^{1}$ According to Abdul Hakim, legal politics is a legal policy that would be implemented or implemented by a particular state government. ${ }^{2}$ These various definitions outline a conclusion that the politics of law is the basic policy of the administration of the state in the field of law that will, is, and has been implemented which is based on the values that exist in society to achieve the goals of the country aspired. ${ }^{3}$

A.M. Yunus Wahid ${ }^{4}$ declare value which is a study of philosophical value (axiology) which is usually used to designate "abstract nouns" which can be interpreted as worth or goodness. The coastal areas of the sea and small islands have a strategic meaning in developing the nation and the welfare of its people. This is because, the wealth of natural resources contained in this region, both biological resources and non-biological resources. However, the natural resource wealth has not been used optimally, one of which is caused by sectoral egos among government agencies. Even sectoral egos that lead to conflicts of authority between these institutions have resulted in damage to the marine environment and small islands, because each institution feels authorized to take advantage, but to blame each other when damage occurs.

The rule of law (supremacy of law) is supremacy of juctice as well as vice versa, both are commutative things. The law is not in the absolute dimension of the law, but the law is in the dimension of absolute justice. ${ }^{5}$ The emergence of conflicts between institutions related to the management of coastal areas and small islands is caused by overlapping laws and regulations. This is because, the interests of each institution are based on the legal basis issued by the Government, in the form of laws, Government Regulations, Presidential Regulations, and Regional Regulations. In other words, environmental damage in the coastal areas of the sea and small islands is caused by unclear authority among the institutions involved in this region, so that with the legal basis given by each of the competent agencies to provide permits for utilization.

The issue of management in the coastal areas of the sea and small islands is increasingly crucial as Law No. 22 Year 1999 concerning Regional Government, which was then replaced by Law Number 32 Year 2004 and now replaced by Law Number 23 Year 2014. In the Regional Government Law, there is a mandate given to the Regional Government to manage coastal area resources the sea and small islands 12 miles to the province. The granting of authority to this region is interpreted as sovereignty, thus creating a horizontal conflict in the sea division in the community. Thus, the problems that occur in the coastal areas of the sea and small islands are not only conflicts between government institutions (sectoral conflicts but also related to the regional authority in managing coastal and small island resources).

\section{B. Arrangements for Management of Coastal Marine Areas According to the 1945 Constitution of the Republic of Indonesia}

The constitution as a document can be a means of paving the way, manipulating and directing economic dynamics in society. The 1945 Constitution of the Republic of Indonesia is a political constitution, an economic constitution and a social constitution both by the State, the civil society and the market. Indonesia's economic constitution outlined in Article 33 of the Constitution of the Republic of Indonesia, adheres to the concept of popular sovereignty, legal sovereignty and God's sovereignty, besides that it is also related to Human Rights.

The 1945 Constitution of the Republic of Indonesia Article 33 Paragraph (3) states that: The earth, water and natural resources contained therein are controlled by the State and are used to the maximum prosperity of the people. Controlled by the State means that the State controls the wealth of marine and coastal resources. While the meaning used as much as possible the prosperity of the people is the legal owner of the wealth of marine and coastal resources is the people of Indonesia. So the position of the State is mutually sovereign over the wealth of marine and coastal resources. State control over marine and coastal resources is an instrument while the sentence as much as possible the prosperity of the people is the ultimate goal of management of marine and coastal resources.

\footnotetext{
${ }^{1}$ c, p. 35

${ }^{2}$ Mahfud, MD, Membangun Politik Menegakkan Konstitusi (Building Politics Upholding the Constitution), Rajawali Pers, Jakarta, 2010, p. 15

${ }^{3}$ Imam Syaukani and A. Ahsin Thohari, Dasar-Dasar Politik Hukum (Fundamentals of Legal Politic), Rajawali Pers, Jakarta, 2013, p. 31-32

${ }^{4}$ A.M. Yunus Wahid, Aktualisasi Kearifan Lokal Menuju Hukum Lingkungan yang Responsif (Actualization of Local Wisdom Towards Responsive Environmental Law), Makassar: Pustaka Pena Press, 2011, p. 73-77

${ }^{5}$ Sukarno Aburaera, et.al., 2010. Filsafat Hukum, Dari Rekonstruksi Sabda Manusia dan Pengetahuan Hingga Keadilan dan Kebenaran (Legal Philosophy, From Reconstruction of the Human Word and Knowledge to Justice and Truth). Penerbit Pustaka Refleksi, Makasssar, p, 70.
} 
All Indonesian people of Indonesia are the owners of the wealth of marine and coastal resources, while the State is only mandated to manage so that the National goals contained in the opening of the 1945 Constitution of the Republic of Indonesia in paragraph IV can be realized. Management of marine and coastal resources is aimed at being able to be enjoyed by all Indonesian people without exception, which in its implementation is oriented to the principles of benefit, justice, and balance, which is aligning with the interests of the nation, participation, transparency and accountability, sustainable and environmentally sound..

Human security is not as narrow as the editorial, because the meaning includes a variety of security dimensions, such as economic security, food security, health security, environmental security, personal security, community security, and political security. ${ }^{1}$ The prosperity of the people is the spirit and ideals of the ultimate welfarestate that can be realized by the State, namely the Indonesian government. Management of marine and coastal resources is one of the instruments to be realized. Strictly speaking, one of the forms of state involvement in the management of marine and coastal resources is to act as a regulator. This aspect of regulation is an absolute right of the State which must not be left to the private sector and is the most important aspect played by the State among other aspects.

State control over production branches that are important to the State and control the livelihoods of many people are controlled by the State, which means that being controlled by the State does not mean that the State is fully in control, but the presence of production branches shows that the implementation of business by the Government can be through State-Owned Enterprises or the State can also submit to private parties or cooperatives. So that the State's position is to make regulations and supervise, so that in the management and operation of businesses by cooperatives and the private sector can take place in accordance with existing regulations that cannot be separated from the principles of the Indonesian economy, namely the principle of kinship and the purpose of the state as set out in the fourth paragraph of the Preamble of the 1945 Constitution of the Republic of Indonesia.

The author can conclude that the meaning of state control as stipulated in the 1945 Constitution of the Republic of Indonesia in Article 33 is that the role of the State in the economy in Indonesia is very important, which is to regulate the running of the economy. In addition, the State can also play a role as a manager and can plaque to give economic ventures to private parties or cooperatives. The meaning of state control in managing the country's economic business can make regulations so that the management and control can be in accordance with the principles and ideals desired in the state that is to prosper the people of Indonesia.

The role of the State cq The government as a regulator aims to ensure that the regulations stipulated can be upheld in a supremely truth, with a view to being able to benefit all people in realizing a sense of social justice. the three pillars of the purpose of the regulation are made so as to provide peace and security in the state. This is in accordance with the legal goals of being upright in supremacy, able to provide a sense of justice and provide benefits in social life.

\section{Regulations for Management of Coastal Marine Areas}

Decentralization in the Coastal and Small Islands According to Law No. 27 Year 2007. The scope of the regulation of this law outline consists of three parts, namely planning, management, and supervision and control with the following description:

\section{Planning}

Planning is carried out through the Integrated Coastal Management approach which integrates various plans drawn up by sectors and regions so that harmony and mutual use can be strengthened. Integrated coastal and small island management is an approach that provides direction for the sustainable use of coastal resources and small islands by integrating various development plans from various levels of government, between terrestrial and marine ecosystems, and between science and management.

Planning for the Management of Coastal Areas and Small Islands is carried out in order to harmonize the interests of economic development with the preservation of coastal resources and small islands and pay attention to the characteristics and uniqueness of the area. The integrated planning is a gradual and programmed effort to make optimal use of coastal resources and small islands in order to produce sustainable economic benefits for the prosperity of the people. The phased plan is accompanied by efforts to control the impact of sectoral development

\footnotetext{
${ }^{1}$ Kadarudin, Human Security in International Law Perspective, Awang Long Law Review, Vol. I No. 1, November 2019, p. 37
} 
that may arise and maintain the sustainability of its resources. Planning of coastal areas and small islands is divided into 4 (four) stages; (i) strategic plan; (ii) zoning plan; (iii) management plan; and (iv) action plans.

Management

Management of coastal areas and small islands includes the following regulatory policy stages:

1. Utilization and exploitation of coastal waters and small islands is carried out through the granting of utilization permits and the Concession Rights of Coastal Waters (Hak Pengusahaan Perairan Pesisir/HP-3). Utilization permits are granted in accordance with the laws and regulations and the authorities of each related institution.

2. The right to cultivate coastal waters (HP-3) is granted in areas of aquaculture or general use water zones except as otherwise regulated.

3. Management arrangements for coastal areas and small islands starting from planning, utilization, implementation, control, supervision, recognition of rights and community empowerment, authority, institutions, to prevention and resolution of conflicts.

4. Management of small islands carried out in an island group or cluster by considering the ecological linkages of economic linkages, and socio-cultural linkages in one bio-ecoregion with the main island or other islands as centers of economic growth.

Supervision and control

Supervision and control is carried out for:

1. Knowing the existence of deviations in the implementation of strategic plans, zoning plans, management plans, and the implications of these deviations on changes in the quality of coastal ecosystems;

2. Encouraging that the utilization of resources in the coastal areas and small islands in accordance with the management plan of the coastal area;

3. Provide sanctions for violations, whether in the form of administrative sanctions such as revocation of licenses or revocation of rights, civil sanctions such as the imposition of fines or compensation; as well as criminal sanctions in the form of detention or confinement.

Decentralization in the Field of Coastal \& Small Islands According to Law Number 1 Year 2014. In general, Law Number 1 Year 2014 includes provisions concerning:

1. Granting the right to the community to propose the preparation of strategic plans, zoning plans, management plans, and action plans for the management of coastal areas and small islands, in Article 14 stipulates that the preparation of RSWP-3, RZWP-3K, RPWP-3-K, and the RAPWP-3$\mathrm{K}$ is carried out by the regional government, the community and the business world. Then the mechanism must involve the community. Local governments that prepare RSWP-3-K, RZWP-3K, RPWP-3-K and RAPWP-3-K are also required to disseminate the concepts of RSWP-3-K, RPWP-3-K, and RAPWP-3-K to get input, responses and suggestions for improvement from the public. ${ }^{1}$

2. Arrangements regarding location permits and management permits for each person and customary law community, local communities, and traditional communities that make use of coastal area and small island resources;

\footnotetext{
${ }^{1}$ Article 14 Law No. 1 Year 2014
} 
Location permit is a permit granted to utilize space from a portion of coastal waters that covers the sea level and water column up to the seabed surface at a certain extent and/or to utilize a portion of small islands. Meanwhile, a management permit is a permit granted to conduct activities in the utilization of coastal water resources and the waters of small islands. ${ }^{1}$

Thus a location permit is needed if someone wants to use space from the island or from the surrounding waters. Meanwhile, if the use of the space is followed by the utilization of resources (mining, fishing, etc.) the location permit must be followed by management. Location permit is an absolute requirement for management permit if someone wants to make use of the space of a portion of the coastal area or small islands. ${ }^{2}$ However, the obligation to have a location permit is exempted from the customary law community. This means that a customary law community group can carry out the utilization and management of a certain coastal area or small islands without the need to report or obtain permission from the local government.

The location permit referred to can only be granted under RZWP-3 and taking into account the preservation of ecosystems, communities, traditional fishermen, national interests, and the right of peaceful passage for foreign vessels. Then if someone does not realize the activities as the location permit he obtained can be subject to administrative sanctions. Location permits can also only be granted to Indonesian citizens, corporations established under Indonesian law, or cooperatives formed by the community. So that foreigners or foreign legal entities cannot apply for location permits. Foreigners or foreign legal entities can only make foreign investments in the business activities of Indonesian-owned businesses that have previously existed on the coast or small islands. The foreign investment must then get permission from the minister.

Regulations regarding the obligation to obtain a location permit as referred to in this law only apply to coastal areas and small islands which are not the territories of indigenous and tribal peoples. Because in this law it is expressly stipulated that the use of coastal waters and small islands in the territory of indigenous peoples by the indigenous and tribal peoples concerned. ${ }^{3}$

Arrangement for the use of small islands and surrounding waters. Utilization of small islands and surrounding waters, aside from having to pay attention to the overall and integrated economic and secological unity with the surrounding large islands, must also be prioritized for certain interests which include: conservation, education and training, research and development, marine cultivation, tourism, fisheries and marine business and the sustainable fishing industry, organic agriculture, animal husbandry and national defense and security. ${ }^{4}$ Nowadays, people are unwittingly destroying the marine environment through waste discharged into the sea. Garbage from food, beverage, and daily life needs to cause a lot of garbage, unfortunately, a lot of garbage is not well managed, with practical thinking and prioritization of convenience, plastic-based waste is then thrown into the ocean and pollute the marine environment. This if left unchecked, the survival of fish and other marine biota will be disrupted, and existing marine resources will not be able to meet the needs of future generations. ${ }^{5}$

Granting authority to ministers, governors and regents/mayors in the management of coastal areas and small islands. Regional governments, namely governors and regents/mayors, have the authority to issue and revoke location and management permits for the use of coastal space areas and small islands. Meanwhile the minister has the authority to issue and revoke licenses for the use of small islands and the use of surrounding waters which have significant impacts and broad coverage and determine changes in the status of the core zone in national conservation areas. ${ }^{6}$

Provincial or regency/city government in accordance with their respective authorities. The provincial government has the authority to take care of it as long as it is cross regency/city. The authority of regional government in PWP \& PPK matters includes planning, utilization (including licensing), conservation and protection, monitoring and evaluation, research and development, and community empowerment. Basically in terms of authority that is the responsibility of subnational governments in this case is the regency/city government that is obtained based on the principle of decentralization is a concept approach to improving the quality of the region. Departing from the conceptual arrangement in autonomy, the autonomous region which is in the Republic

\footnotetext{
${ }^{1}$ Article 1 number 18 Law No. 1 Year 2014

2 Article 16 Law No. 1 Year 2014

${ }^{3}$ Law Number 1 Year 2014, Part One concerning Permits

${ }^{4}$ Article 23 Law No. 1 Year 2014

5 Kadarudin, State Commitment to Fights Sea Pollution by Plastic Waste in United Nations Convention on Climate Change, Jurnal Ilmu Hukum “The Juris", Vol. II No. 1 June 2018, p. 1

${ }^{6}$ Article 50 Law No. 1 Year 2014
} 
of Indonesia as the Unitary State adheres to the principle of decentralization in the administration of government in the regions, as well as providing opportunities and flexibility to the regions to implement autonomy.

In line with the principle of regional autonomy and the principles of its implementation including the principle of decentralization to carry out its authority in carrying out the tasks and functions of government in the region should be given full authority on the management of coastal areas and small islands due to the linkage of the region that better knows the potential of natural resources in that area is the regency/city government. The existence of the principle of co-administration is actually intended to ease the burden of government administration by the central government to the provincial and $\mathrm{v}$ and facilitate the implementation of tasks and solving problems faced by each region.

In the field of management of coastal areas and small islands it can be seen that in its implementation there are often problems in the field, so with the assistance task can help to resolve problems in the field that can lead to very detrimental implications in carrying out the functions of regency/city government. The authority possessed by the regional government is a form of realization in increasing the role of the region in the implementation of regional autonomy.

To accelerate the realization of community welfare and development in the regions by taking into account the principles of democracy, equity and justice, the need for the value of efficiency and effectiveness in the administration of regional governments by taking into account the relationship between the central government and the provincial and regency/city government. Since it was passed, the Law No. 23 Year 2014 was adopted, which is a substitute for Law 32 Year 2004 which has a very broad impact, especially in the management of coastal areas and small islands in Indonesia, especially in regency/city areas.

Based on the division of governmental affairs in Article 9 of Law No. 23 Year 2014 the authority possessed by regencies/cities is classified in concurrent government affairs which causes restrictions on regency/city government in carrying out government that is contrary to the concept of regional autonomy as well as the spirit of broadest autonomy. Affairs of maritime affairs and fisheries become concurrent governmental affairs based on Article 12 paragraph (3) of Law 23 Year $2014^{1}$ in which the matter is not a matter of regency/city regional government but becomes a matter for the provincial and central government based on the authority regulated by Law 23 Year 2014.

To carry out the authority of regency/city government in the field of management and utilization in the sector of coastal areas and small islands handed over to the central government and provincial government so as to result in the implementation of regency/city governmental affairs in terms of management and utilization in the coastal and island sector small islands changed which had been decentralized and after the enactment of Law 23 Year 2014 changed to deconcentration set by the central government on the management and utilization of coastal areas and small islands. Based on the attachment of the division of government affairs in the field of maritime affairs and fisheries Law 23 Year 2014, the regency/city area no longer deals with the management of coastal areas and small islands.

Meanwhile, the provincial government which is characterized by the archipelago gets an abundance of authority from the Central Government. This is as outlined in Article 28 paragraph (2) of Law No. 23 Year 2014, that in addition to exercising authority to manage resources in the sea area, for the Province of the archipelago, the Central Government assigns the exercise of its authority in the maritime sector. Assignments can only be carried out if the Provincial Government of the archipelago has fulfilled the norms, standards, procedures and criteria set by the Central Government. Regarding norms, standards, procedures and criteria, Law No. 23 Year 2014 mandates regulations in the form of Government Regulations.

After the enactment of Law 23 Year 2014 which until now does not yet have a Government Regulation as a rule that implements the law and there is a conflict of authority of the regency/city government against the PWP \& PPK Law in terms of management of coastal areas and small islands. According to Abdul Azis as Head of the Capture Division, coastal marine and small islands of the marine and fisheries service in South Sulawesi Province, argues that after the enactment of Law 23 of 2014 the provincial government has exercised authority by cooperating with regency/city governments, for example, regarding zoning plan making. Regencies/cities that have

\footnotetext{
${ }^{1}$ Selected governmental affairs as referred to in Article 11 paragraph (1) include: a. marine and fisheries; b. tourism; c. agriculture; $d$. forestry; e. energy and mineral resources f. trade; g. industry; and h. transmigration
} 
already made zoning plans to be submitted to the provinces are then determined in the form of regional regulations so that there are no more differences in zoning plans for each district. ${ }^{1}$

Based on the interview above it can be said that the provincial government continues to coordinate with the regency/city government by continuing what the regency/city government has done in relation to the management of coastal areas and small islands, then the results of the continued work are determined through provincial regional regulations.

In carrying out the authority to manage and utilize coastal areas and small islands which are now the authority of the provincial government based on Law 23 Year 2014, the central government has determined arrangements relating to this matter through the Minister of Maritime Affairs and Fisheries of the Republic of Indonesia Regulation Number 23/KP/2016 concerning Management of Coastal Areas and Small Islands.

Based on the Minister of Maritime Affairs and Fisheries of the Republic of Indonesia Regulation Number $23 / \mathrm{KP} / 2016$, the authority owned by the regency/city government in terms of management of coastal areas and small islands has been revoked. Governors and Regents/Mayors who will be the reference for carrying out government affairs are concurrent which have been determined by the central government. In the consideration of the Minister of Maritime Affairs and Fisheries of the Republic of Indonesia Regulation Number 23/KP/2016 it is stated that in the framework of implementing synergy between the Central Government and the regions, ministries/non-ministerial government institutions, the Minister of Maritime Affairs and Fisheries Regulation No. 34/PERMEN-KP/2014 concerning Management of Coastal Areas and Small Islands needs to adjust with Law Number 23 Year 2014 concerning Regional Government, as amended several times, most recently Law Number 9 Year 2015 concerning Second Amendment to Law Number 23 Year 2014 concerning Regional Government.

Based on the explanation above, it can be said that the presence of Regulation Number 23/KP/2016 as a legal form so that the implementation of the authority owned by the province as previously the authority was carried out by regency/city governments based on Law No. 32 Year 2004 and PWP \& PPK Law. The affirmation of the authority of the Provincial Government is stated in Article 2 of Regulation Number 23/KP/2016. Article 2 paragraph (1) states that this Ministerial Regulation is intended as a norm, standard and guideline for the Provincial Government in carrying out the planning of coastal areas and small islands. Paragraph (2) further states that the purpose of this Ministerial Regulation is to realize an integrated Coastal and Small Islands Management Plan at the Provincial Government level.

The provincial government in the future in carrying out management and utilization of coastal areas and small islands is guided by Regulation Number $23 / \mathrm{KP} / 2016$ as stated in the provisions of Article 2 of Regulation Number $23 / \mathrm{KP} / 2016$ in order to optimize the management of coastal areas and small islands in the regions.

In the management of coastal marine resources and small islands whose rapid development often conflicts arise between various stakeholders. From the search results, there are 21 laws and 6 international provisions that have been ratified or only as a reference (soft law). These laws provide mandates to 14 development sectors in regulating the use of coastal and small island resources, both directly or indirectly. The fourteen sectors include defense, mining, industry, transportation, fisheries, tourism, agriculture, forestry, conservation, spatial planning, public works, defense, finance and local government.

Based on these sectoral regulations, there is a conflict of interest between institutions in managing marine and small island resources. In fact, along with the era of regional autonomy, there is a tendency for regional governments to make regional regulations based on their importance in increasing local revenue (Pendapatan Asli Daerah/PAD). Therefore, this is feared to lead to legal uncertainty in development in the coastal areas of the sea and small islands which can lead to damage to resources and the environment.

The management of marine areas in the area is regulated in Law Number 23 Year 2014 in Chapter V of the Provincial Authority of the sea and the province of the archipelago, the first part of the authority of the provincial region at sea. The chapter clearly states that the authority to manage maritime territories in the regions is directly attached to the authority of the provincial government. Different from the nomenclature of the management of marine areas in the regions in Law Number 23 Year 2014 which explains that what is meant by the regions in Law Number 32 Year 2004 is autonomous regions, hereinafter referred to as regions, namely the legal community unit that has territorial boundaries that are has the authority to regulate and manage government

\footnotetext{
${ }^{1}$ Interview with Abdul Aziz said, the Office of Maritime Affairs and Fisheries of South Sulawesi Province on November 17,
} 2016 
affairs and the interests of the local community according to their own initiative based on the aspirations of the people in the system of the Unitary State of the Republic of Indonesia. The autonomous region is located in the regency/city domain rather than the Province, so that the shift in authority further reduces the nature of regional autonomy and the role of the regency/city government as the organizer of regional autonomy to be creative in advancing and exploiting the marine potential in the region. The regulation of the authority to manage maritime territories in the regions is based on Law Number 32 Year 2004 and Law Number 23 Year 2014.

\section{Conclusion}

The regulation of management of marine resources in Indonesia still occurs disproportionate tugging of authority between the Central Government and Local Governments resulting in tensions that lead to a conflict of authority so that there is a need for assertiveness and clarity in the division of authority for management of marine resources between the Central Government and The Regional Government proportionally really takes into account national interests and the interests of the region itself. In addition, the decentralization policy on marine resource management is carried out half-heartedly so that overlapping authority occurs between the Central Government and Regional Governments so that synchronization of laws and regulations governing the obligation to form zoning regulations that were initially regency/city-based to provincial-based.

\section{References}

A.M. Yunus Wahid, Aktualisasi Kearifan Lokal Menuju Hukum Lingkungan yang Responsif (Actualization of Local Wisdom Towards Responsive Environmental Law), Makassar: Pustaka Pena Press, 2011.

Abd. Asis, et.al., Strategic policy of the Government of Indonesia In the Field of Maritime and Fisheries Affairs, International Journal of Scientific and Research Publications, Volume 6, Issue 12, December 2016.

Achmad Ruslan, 2011, Peraturan Perundang-Undangan Sebagai Sarana Hukum Penyelenggaraan Negara (Legislation as a Means of State Administration), Professor's Oration.

An An Chandrawulan, 2014, Hukum Perusahaan Multinasional, Liberalisasi Hukum Perdagangan Internasional dan Hukum (Multinational Corporate Law, Liberalization of International Trade Law and Law), PT. Alumni, Bandung.

Bagir Manan, Politik Hukum Untuk Otonomi Daerah (Legal Politic for Regional Autonomy), Public Lecture at the Postgraduate Faculty of Law at Syiah Kuala University, Banda Aceh, 2013.

Farida Patittingi, 2013, Dimensi Hukum Pulau-Pulau Kecil di Indonesia (The Legal Dimension of Small Islands in Indonesia), Rangkang Education Yogyakarta.

Imam Syaukani and A. Ahsin Thohari, Dasar-Dasar Politik Hukum (Fundamentals of Legal Politic), Rajawali Pers, Jakarta, 2013.

Jimly Asshiddiqie, 2010, Green Constitution, Nuansa Hijau Undang-Undang Dasar Republik Indonesia Tahun 1945 (Green Constitution, Green Shades of the 1945 Constitution of the Republic of Indonesia), Rajawali Pers, Jakarta.

Kadarudin, State Commitment to Fights Sea Pollution by Plastic Waste in United Nations Convention on Climate Change, Jurnal Ilmu Hukum “The Juris”, Vol. II No. 1 June 2018.

Kadarudin, Human Security in International Law Perspective, Awang Long Law Review, Vol. I No. 1, November 2019.

Mahfud, MD, Membangun Politik Menegakkan Konstitusi (Building Politics Upholding the Constitution), Rajawali Pers, Jakarta, 2010.

Department of Maritime Affairs and Fisheries of the Republic of Indonesia, 2001, Pedoman Umum Pengelolaan Pulau-pulau Kecil yang berkelanjutan dan berbasis masyarakat (General Guidelines for the Management of Small Islands that are sustainable and community-based), Jakarta. 
Muhammad Ali Safa'at, Sentralisasi dalam UU Nomor 23 Tahun 2014 tentang Pemerintahan Daerah (Centralization in Law Number 23 Year 2014 concerning Regional Government), delivered at the focus group discussion "Inventory Issues Law No.23 of 2014 concerning Regional Government” organized by the Association of Regency Governments throughout Indonesia (Asosiasi Pemerintah Kabupaten seluruh Indonesia/APKASI). Jakarta, 15 September 2015.

Padmo Wahjono, Indonesia Negara Berdasarkan atas Hukum (Indonesia is Based on Law), Ghalia Indonesia, Jakarta, 1986.

Peter Mahmud Marzuki, 2003, Penelitian Hukum (Legal Reaearch), Prenada Media, Jakarta.

Roni Hanitijo Soemitro, Metodologi Penelitian Hukum dan Jurimetri (Legal and Jurimetry Research Methodology), Penerbit Ghalia Indonesia Jakarta, 1998.

Imam Syaukani and A. Ahsin Thohari, Dasar-Dasar Politik Hukum (Fundamentals of Legal Politic), Rajawali Pers, Jakarta, 2013.

Sukarno Aburaera, et.al., 2010. Filsafat Hukum, Dari Rekonstruksi Sabda Manusia dan Pengetahuan Hingga Keadilan dan Kebenaran (Legal Philosophy, From Reconstruction of the Human Word and Knowledge to Justice and Truth). Penerbit Pustaka Refleksi, Makasssar.

Sugeng Budiharsono, 2001, Teknik Analisis Pembangunan Wilayah Pesisir dan Lautan (Coastal and Ocean Territory Development Analysis Techniques), Jakarta.

Teuku M. Radhie, Pembaharuan dan Politik Hukum dalam Rangka Pembangunan Nasional (Legal Reform and Politics in the Framework of National Development), Jurnal Prisma, No. 6 Tahun II, 1973. 